\title{
『日帝强占初期韓半島刊行日本語民間新聞の文藝物』叢書
}

\author{
Inkyung UM(嚴仁卿 : Professor of Global Institute for Japanese Studies Korea University) \\ 四 uik6650@korea.ac.kr
}

(韓国)高麗大学校グローバル日本研究院教授。日本語詩歌文学、日韓比較文化論。『文学䧱誌『国 民詩歌』と韓半島における日本語詩歌文学』(ソウル：亦楽. 2015)、「A Study of the Formation of Japanese Language Literature in Colonial Korea : Japanese Magazines, Japanese Translations of Joseon Literature, and Traditional Japanese Poetry」 (INTERDISCPLINARY STUDES OF LTTERATURE Vol.1. No.1. Hong Kong : Knowledge Hub Publishing Company LTD, 2017)、『韓半島と日本語詩歌文学』(ソウル：高麗大 学校出版文化院, 2018)、「Changes to Literary Ethics of Tanka Poets on the Korean Peninsula during the Japanese Colonial Eras (FORLM FOR WORLD LITERATURE STUDIES Vol.10. No.4. Hong Kong Knowledge Hub Publishing Company LTD, 2018)など。

\section{Japanese-Language Literary Works Published in Non-Government Newspapers in Korea During the Early Colonial Period}

This book review examines a series of eight volumes dealing with literary works featured in privately-owned Japanese language newspapers published in Korea from 1876 to 1920 during the early Japanese colonial era. They are: Catalog of Literary Works Published in Japanese Language Newspapers in the Early Japanese Colonial Era Volumes I to III, Translations of Literary Works Published in Japanese Language Newspapers in the Early Japanese Colonial Era Volumes I to IV, and A Study of Literary Works Published in Japanese Language Newspapers in the Early Japanese Colonial Era. Extensive joint research was conducted in order to compile this series. Extant copies of Japanese language newspapers published in the early days of the Japanese colonial era, which had not been studied in detail due to the lack of knowledge as to their whereabouts, were collected, catalogs of literary works were created and legible literary works in a range of genres were translated. This compilation is significant in that it reveals the lived experience and perspective of the Japanese who resided on the Korean peninsula at that time as well as the relationship between Japan and colonial Joseon. It can also serve as an important resource for future comparative studies, which twin works of this period with literary works created after the 1920s or with literary works published in Keijo Nippo (Kyungsung ilbo), the organ of the Japanese Government-General of Korea.

Keywords Non-Government Newspapers(民間新聞), Literary Works(文芸物), List(目 録集), Translation Collection(翻訳集), Research Volume(研究書) 
高麗大学校グローバル日本研究院の $<$ 日帝强占初期韓半島刊行日本語民間新聞の文藝物研究事 業>事業団が、韓国研究財団支援の3年間(2016年 2019年)共同研究を終えて、その結果を今 年、全8巻の叢書として報告した。その構成は『日帝强占初期日本語民間新聞文藝物目録集』(以 下、『目録集』が3巻で、『日帝强占初期日本語民間新聞文藝物翻訳集』(以下、『翻訳集』)が4巻、『韓 半島刊行日本語民間新聞文藝物研究』(以下、『研究書』)となっており、2020年5月ポゴサから刊 行した。

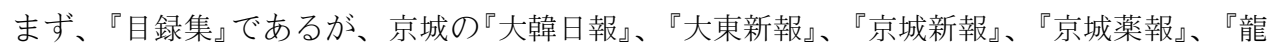
山日之出新聞』、『法廷新聞』、『京城日日新聞』、仁川の『朝鮮新聞』(前身『朝鮮新報』)、『朝鮮日日 新聞』、釜山の『朝鮮新報』、『朝鮮時報』、『朝鮮日報』、『釜山日報』、大邱の『朝鮮』、平壤の『平 壤新報』、『平壤日日新聞』、新義州の『平安日報』など17種の新聞の文芸物について、日付・紙 面・段・タイトル・著者・分類・備考(誤った情報などの記載)を丹念にリストアップしたもので ある。目を通してみると、文芸物だけでも非常に多様なジャンル一小説・詩歌・随筆・紀行・講 談・評論・広告など一が発表されていることと、ことに詩歌は短歌・俳句・川柳・都々逸・漢 詩・新体詩・自由詩などが絶えず文芸欄に掲載されていて、文芸物の主流をなしていたことが 指摘できる。『目録集』3巻目の末尾には17種の新聞の概要が記されており、全ての記事の目録で はないものの、日本人の主要な居留地域でもあった6個所の都市における民間新聞の大体の変遷 (発行時期、発行地や題号の変更など)を辿ることができて、良い参考となる。

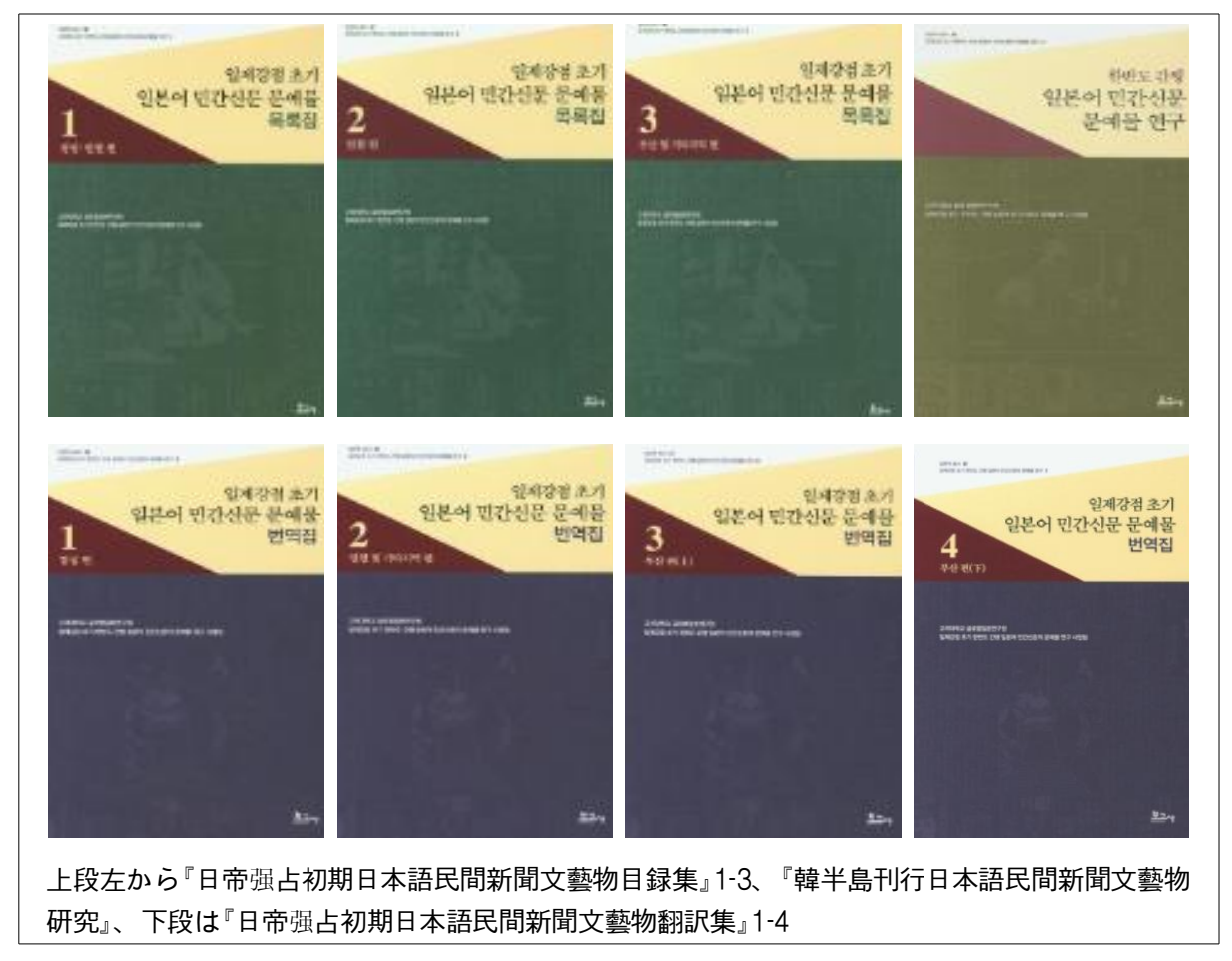


次は4巻の『翻訳集』である。『目録集』に挙った文芸物の中で、主要作家の未発見作品、時代状 況を反映したもの、読者参加型の文芸、多様なジャンルの反映、日本語文芸物の流通の経路が 窥えるもの、翻訳文学という7つの基準に従って選んだものが翻訳されている。韓半島のよう な「外地」においては、大衆文学の発展の様相や本格的な募集と選別という文壇システムは、 1920年以降になってからやっと論じられるようになったと思われがちだったが、それ以前の 早い段階から存在していたことが顕になった点でも興味深い。しかも民間新聞だけあって、新 聞社の折々の事情によっては紙の質や植字の状態、インク、輪轉機のコンディションが一定し ているどころか満足できる状態であったとは考えられない。これは技術の面でずっと発展した はずの1930年代にも民間新聞の記者たちがよく提起していた問題なので、1920年以前の印刷環 境がいかに劣悪だっかたは想像にかたくない。翻訳にも読めない部分の処理などが見えて残念 であるが、とはいえ、判読可能な範囲に挑み、これくらいの文芸物を韓国の研究者たちが訳し て提供した功労は認めたい。

最後に『研究書』であるが、翻訳探偵小説の連載物、「内地」作家の連載小説、和歌・俳句のよ うな伝統詩歌など、それぞれの項目ごとに論考が収められいる。『目録集』と『翻訳集』で紹介さ れた作品とジャンルに関するこのチームの論考が柱となっているが、「在朝日本人の発行した 民間新聞の全体像」という特集があって、韓半島全域で発行された民間新聞の全体像を締めく くっている。

植民地期に刊行された様々な生の文献や記録から推し測ることのできる、19世紀末から20世 紀前半まで韓半島で刊行された新聞の数は 100 以上を数えると言う。機関紙でもない民間新聞と もなると、資料の散逸は著しく、現存資料の入手も至難の業で、やっと残っている資料すら欠 号が多いのは勿論、判読も難しい上、誤字・誤植・脱字も多いわけだ。このような環境と現況 の下で3年間の協同作業の報告として世に出た『目録集』、『翻訳集』、『研究書』であるが、この叢 書が結果報告で終わるのを望まない。というのは、この研究は民間新聞を1920年以前までを対 象にしているが、3.1独立運動の後、朝鮮総督府の文化政策への変換以降の文芸活動とのつなが りについても対照的に考察されるべきであろうし、また『京城日報』という総督府機関紙との本 質的な違いなども明かさなければならないからである。 